\title{
Prevention and Intervention Strategies for Promoting Resilience in Disadvantaged Children
}

\author{
Paul R. Smokowski \\ University of Wisconsin-Madison
}

\begin{abstract}
This article addresses the emergence of a resilience-based prevention practice perspective that focuses on positively affecting the development of disadvantaged, at-risk children. Significant progress has been made in understanding risk and resilience processes; however, use of the field's advances in applied settings has lagged. The article will attempt to bridge this gap by reviewing relevant issues in program design, implementation, and evaluation from a resilience perspective. Risk and resilience dynamics are briefly highlighted to illuminate theoretical routes for promoting positive adaptation. Trends in constructing preventive programs are underscored, focusing on ecological routes to behavioral and environmental change. Finally, prevention and early intervention programs for disadvantaged children ages 3-9 illustrate issues in program conception and effectiveness. Methodological concerns in evaluation of these programs are discussed, and future recommendations are given.
\end{abstract}

In the past 2 decades, enthusiasm for investigating childhood resilience and preventive interventions has developed on parallel trajectories. Both areas have enjoyed growing public attention and have begun to coalesce fragmentary research attempts into cohesive bodies of research. Yet growth has not occurred without stumbling blocks. The study of resilience has struggled to emerge from the overarching shadow of pathology, and prevention programs have been accused of lacking strong theoretical foundations or rigorous evaluation. ${ }^{1}$

With common roots in epidemiological mapping of risk processes, these estranged disciplines are just beginning to rediscover each other and intertwine more effectively to reinforce practice applications and

Social Service Review (September 1998).

(C) 1998 by The University of Chicago. All rights reserved.

0037-7961/98/7203-0003\$02.00 
program effectiveness. ${ }^{2}$ The traditional "problem-focused" orientation, with its preponderance of retrospective research designs, proved to be of little use to prevention programs and public health investigators who were trying to fashion health-promotion interventions. Prevention models within this framework were based on values rather than facts because pathology data provided little direction for skills-building prevention or intervention packages, and retrospective research designs shed limited light on factors promoting positive development. ${ }^{3}$ This led to growing dissatisfaction and the gradual shift to include, and at times emphasize, resilience. This dynamic is further reinforced by the current prominence of ecological approaches, which lend themselves to both resilience and prevention intervention frameworks. ${ }^{4}$

I will begin to develop a resilience-based prevention practice perspective by highlighting risk and resilience dynamics. I will then outline prevention and early intervention programs for disadvantaged children ages 3-9 to illustrate issues in program conception and effectiveness. Each of the programs has elements, which I call "modifiable mediators," that lend themselves to resilience-based interventions. These pathways for intervention are briefly outlined. Finally, I will discuss some methodological concerns in evaluations.

\section{Risk and Resilience}

Risk factors represent "any influences that increase the probability of onset, digression to a more serious state, or maintenance of a problem condition." ${ }^{5}$ There are several important mechanisms through which risk can be transmitted. Risk traits, on the one hand, are individual predispositions that heighten vulnerability to negative outcomes. Temperament or a family history of depression or heart disease are examples of such traits. Contextual effects, on the other hand, are environmental correlates or conditions conducive to risk. These effects can be indirect (e.g., neighborhood poverty, high unemployment) or direct (e.g., inadequate parenting, peer pressure). Links between different risk variables often occur, forming risk chains. Poverty, for instance, commonly coincides with parental unemployment, single-parent households, high parental stress, lower educational attainment, and a complex array of other risk factors. This accumulation of risk and stress has been shown to have strong deleterious effects on children's development. ${ }^{6}$ Michael Rutter's investigation of family risk, for instance, showed that when two or more risk factors are present in a child's life, the probability of subsequent disorder is significantly bolstered. ${ }^{7}$

Resilience, in contrast, denotes positive adaptation and competence despite the presence of substantial risk. "Resilience factors" have been described by some authors as adaptive processes internal to the child, while "protective factors" exist in the environment. " "Resilience strings" are chains of factors that promote positive outcomes-the adaptive 
equivalent to risk chains. ${ }^{10}$ Protective mechanisms are commonly thought to promote resilience by interacting with risk factors. In this model, a protective effect is present if an attribute enhances functioning for highrisk individuals but makes no difference for their low-risk counterparts. Protection is also at play when high levels of a variable mediate stress, and yet when low levels of the variable are present, an individual's competence decreases. For instance, parental supervision protects against adolescent delinquency. When supervision is high, there is little delinquent behavior. When supervision is low, delinquency increases. Conversely, vulnerability to risk exists when high levels of a variable are associated with declines in functioning while low levels are not. Parental psychopathology, for instance, leaves children vulnerable to mental health problems; however, low levels or the absence of parental psychopathology is not associated with childhood mental health problems. Important protective mechanisms that moderate or mediate risk include intelligence among preadolescents, gender, social skills, parent-child relationships, and school experiences. Exactly how they work is not well understood, but it is hypothesized that these mechanisms may intercede by reducing risk's effects, reducing negative chain reactions, establishing and maintaining self-esteem and self-efficacy, or opening opportunities. ${ }^{11}$

Research into risk and resilience has grown increasingly complex. Risk factors and protective processes are now considered to exist and interact on a variety of levels with individual, familial, societal, or cultural manifestations. Generic, overarching factors have been mapped, as well as processes specific to a particular problem. ${ }^{12}$ Ecological complexities introduce multideterminism, in which many environmental influences contribute to any given adaptive or maladaptive behavioral outcome. Domain specificity has also become prominent. Functional competence in one arena does not necessarily indicate positive adaptation in other behavioral, cognitive, or emotional spheres of functioning. ${ }^{13}$ Similarly, levels of risk, resilience, and protection are hypothesized to fluctuate (in some domains more than in others) across developmental periods, to vary by gender, and to show variations by race or ethnicity. ${ }^{14}$

\section{Resilience-Based Intervention Strategies}

Only recently has resilience research accumulated enough solid data to begin to offer program planners productive strategies for prevention and intervention. As such, resilience research has begun to reach its potential in aiding program planning through the "alterable factors" perspective.

Ann Masten outlined four distinct strategies for fostering individual resilience and bolstering adaptive outcomes. ${ }^{15}$ Reducing vulnerability and risk was the first approach and is strongly couched in primary prevention methods. Mark Fraser and Maeda Galinsky write, "Risk factors should guide intervention efforts, and the goal of intervention should be 
to reduce the effect of specifically targeted risk factors significantly." ${ }^{16}$ In this approach, programs attempt to circumvent high-risk situations before the individual encounters their effects. Contraception and "safesex" strategies, for example, are designed to intervene before teenagers contract a sexually transmitted disease or conceive a baby. Early childhood interventions such as Head Start, which attempts to raise children's cognitive abilities to acceptable levels before school entry, are other examples of this approach.

The second approach to promoting positive outcomes lies in reducing stressors and "pileup." Consider poverty. Low socioeconomic status often coincides with or precipitates risk factors such as parental distress, marital discord, parental substance use, inadequate access to health services, and lapses in parental supervision, among others. These risk factors become risk chains, which subsequently heighten the likelihood of child maltreatment, adolescent alcohol and drug use, delinquency, and teenage pregnancy. If intervention can lessen the effect of the individual stressors or disrupt their accumulation, the risk chain may break down. Many early childhood programs for disadvantaged children attempt to do this by integrating parenting-skills training and parent-child attachment elements into their interventions. Theoretically, despite the stressors inherent in poverty, if high-quality parenting remains as a protective factor, the likelihood of child maltreatment, teenage substance use, delinquency, and so forth, should not be heightened.

Increasing available resources is a third strategy for facilitating adaptive outcomes. Yet again, poverty serves as an example. Poverty elevates a child's vulnerability to every kind of risk, causing more social, behavioral, and physical problems than are present in nearly any other type of situation. Simultaneously, it often reduces access to high-quality resources that can help in coping with the stress and strain, causing a situational double jeopardy for disadvantaged children. ${ }^{17}$ If access to community health care, educational services, or employment-oriented and recreational services could be enhanced, many of poverty's concomitant sources of stress might be lessened. Some straightforward examples of this dynamic are found in programs that try to prevent childhood diseases through free immunization clinics or promote "safe sex" by disseminating free condoms.

The final strategy Masten offers is mobilizing protective processes. ${ }^{18}$ Protective factors may aid in interventions by directly decreasing dysfunction, buffering the effects of risk factors, preventing the onset of a particular risk factor, or by breaking the risk chain that fosters disorder. ${ }^{19}$ Mapping such protective processes for intervention targets may be the single most important contribution resilience research makes to program development. Protective mechanisms operating for high-risk children who do not suffer negative outcomes must be understood and used in fashioning intervention programs. Providing a supportive adult to a child at risk in a Big Brother or Big Sister program is an example of 
mobilizing a well-researched protective factor. A wide range of protective factors that may serve as targets for interventions are delineated in table 1 .

Similar to mobilizing protective factors is attempting to foster "resilience strings" of beneficial behavior. ${ }^{20}$ An intervention that encourages academically successful students to tutor their less-accomplished peers is an example of such an approach. ${ }^{21}$ Beyond the benefits to the lessaccomplished student, the successful child experiences a sense of mastery and also enhances his or her communication skills or social skills, which are useful protective factors in the social domain.

The strategies outlined above are in no way mutually exclusive. In fact, multifaceted prevention and intervention programs regularly integrate several of these objectives. The early intervention programs Head Start and Child Parent Centers, which will serve as in-depth examples later in the discussion, have multiple targets for intervention effectiveness, thus mobilizing several "modifiable mediators" using a variety of approaches. Notably lacking in the literature, however, are studies of the effectiveness of programs designed to foster resilience. ${ }^{22}$ Extrapolations commonly have to be made from allied outcome variables such as academic achievement or "social competence" as manifested by such measures as academic tests and IQ scores. ${ }^{23}$ This practice fosters fragmentation and contributes to the dearth of application knowledge.

\section{Wedding Prevention and Resilience}

Prevention programs offer a natural opportunity to wed resilience theory to practice. Interest in prevention has grown substantially in the last 2 decades. Whether the focus is on drug abuse, teenage pregnancy, school failure, delinquency, nutrition, or a host of other problems, the primary goal of prevention is to reduce the incidence, duration, or intensity of undesirable outcomes. $^{24}$

The Institute of Medicine has provided careful categories for efforts in this area. ${ }^{25}$ "Universal" prevention interventions target an entire population group, regardless of individualized risk status. "Selective" prevention programs, in contrast, target high-risk subpopulations. Biological, psychological, or social risk factors that indicate heightened vulnerability are used to identify groups to target. Finally, "indicated" prevention interventions target high-risk individuals after some detectable signs of disorder have begun to surface but before the problem has grown substantially.

The Institute of Medicine's new terminology highlights the importance of understanding risk factors when designing interventions. This is a significant step forward in forming an empirically founded, resiliencebased practice paradigm. Integration of risk and resilience processes, modifiable mediators, and protective factors in selecting targets and methods for change has become an increasingly important undertaking 
Table 1

Childhood and Adolescent Risk and Protective Factors by Problem Area

\begin{tabular}{|c|c|c|c|}
\hline \multirow[b]{2}{*}{ Problem Area } & \multicolumn{3}{|c|}{ Risk FACTORS } \\
\hline & Individual & Family & Environmental \\
\hline $\begin{array}{l}\text { General, } \\
\text { nonspecific }\end{array}$ & $\begin{array}{l}\text { Gender (varies by situ- } \\
\text { ation and develop- } \\
\text { mental phase) } \\
\text { Biomedical problems } \\
\text { Lower IQ } \\
\text { Difficult temperament } \\
\quad \text { (infancy) }\end{array}$ & $\begin{array}{l}\text { Child maltreatment } \\
\text { Parent conflict } \\
\text { Parental } \\
\text { psychopathology } \\
\text { Poor parenting }\end{array}$ & $\begin{array}{l}\text { Few opportunities for } \\
\quad \text { education and } \\
\text { employment } \\
\text { Racial discrimination } \\
\text { Poverty }\end{array}$ \\
\hline $\begin{array}{l}\text { Child abuse } \\
\text { and neglect }\end{array}$ & $\begin{array}{l}\text { Parents: } \\
\text { Psychological } \\
\text { distress } \\
\text { Low self-esteem } \\
\text { Substance abuse } \\
\text { Children: } \\
\text { Health } \\
\text { complications } \\
\text { Low intellect } \\
\text { Developmental } \\
\text { abnormalities } \\
\text { Difficult tempera- } \\
\text { ment (infancy) } \\
\text { Noncompliant } \\
\text { behavior }\end{array}$ & $\begin{array}{l}\text { Parental psychological } \\
\text { distress } \\
\text { Lack of or conflictual } \\
\text { social support } \\
\text { Marital discord } \\
\text { Lack of positive inter- } \\
\text { actions among } \\
\text { family members } \\
\text { Single parenting } \\
\text { Parental } \\
\text { unemployment } \\
\text { Family poverty }\end{array}$ & $\begin{array}{l}\text { Poverty, lack of } \\
\text { resources } \\
\text { Unemployment } \\
\text { Lack of support } \\
\text { systems } \\
\text { Lack of or inadequate } \\
\text { housing, health } \\
\text { care, helping } \\
\text { services } \\
\text { High rate of crime } \\
\text { and violence } \\
\text { Discrimination }\end{array}$ \\
\hline
\end{tabular}

\begin{tabular}{|c|c|c|c|}
\hline $\begin{array}{l}\text { Alcohol and } \\
\text { drug use }\end{array}$ & $\begin{array}{l}\text { Family history of } \\
\text { alcoholism } \\
\text { Sensation-seeking } \\
\text { orientation } \\
\text { Poor impulse control } \\
\text { Attention deficits } \\
\text { School failure } \\
\text { Association with drug- } \\
\text { using peers }\end{array}$ & $\begin{array}{l}\text { Family conflict } \\
\text { Poor parent-child } \\
\text { bonding } \\
\text { Poor family manage- } \\
\text { ment practices } \\
\text { Poor family } \\
\text { communication } \\
\text { Family alcohol and } \\
\text { drug use }\end{array}$ & $\begin{array}{l}\text { Availability of alcohol } \\
\text { and drugs } \\
\text { Tolerant norms on } \\
\text { substance use } \\
\text { High population } \\
\text { density, high crime } \\
\text { rates, and residen- } \\
\text { tial mobility } \\
\text { Poverty, economic } \\
\text { deprivation }\end{array}$ \\
\hline
\end{tabular}




\begin{tabular}{|c|c|c|c|}
\hline \multicolumn{3}{|c|}{ Protective Factors } & \multirow[b]{2}{*}{ Prevention-Invervention Focus } \\
\hline Individual & Family & Environmental & \\
\hline $\begin{array}{l}\text { Easy temperament } \\
\quad \text { (infancy) } \\
\text { Self-esteem and } \\
\text { self-efficacy } \\
\text { High IQ } \\
\text { Competence } \\
\text { playing roles }\end{array}$ & $\begin{array}{l}\text { Social support } \\
\text { Presence of caring } \\
\text { adult } \\
\text { Positive parent-child } \\
\text { relationship } \\
\text { Effective parenting }\end{array}$ & $\begin{array}{l}\text { Opportunities for } \\
\text { education, } \\
\text { growth, } \\
\text { employment, } \\
\text { achievement } \\
\text { Sense of community }\end{array}$ & $\begin{array}{l}\text { Identify key risk factors and match } \\
\text { effective intervention to reduce } \\
\text { vulnerability } \\
\text { Strengthen protective processes } \\
\text { Emphasize strengths rather than } \\
\text { deficits } \\
\text { Integrate empowerment models }\end{array}$ \\
\hline $\begin{array}{l}\text { Parents: } \\
\text { Competent } \\
\text { parenting } \\
\text { Adequate social } \\
\text { supports } \\
\text { Children: } \\
\text { Competent } \\
\text { behavior } \\
\text { Higher IQ } \\
\text { High self- } \\
\text { esteem } \\
\text { Being seen as } \\
\text { affectionate } \\
\text { (infancy) } \\
\text { Being older at } \\
\text { time of mal- } \\
\text { treatment } \\
\text { Outgoing } \\
\text { nature }\end{array}$ & $\begin{array}{l}\text { Family cohesiveness } \\
\text { Resilient parents } \\
\text { (often lead to re- } \\
\text { silient children) } \\
\text { Positive role } \\
\text { modeling } \\
\text { Presence of siblings } \\
\text { Marital harmony } \\
\text { Availability of sup- } \\
\text { portive family } \\
\text { members }\end{array}$ & $\begin{array}{l}\text { Availability of sup- } \\
\text { portive friends, } \\
\text { teachers, } \\
\text { neighbors } \\
\text { Community well- } \\
\text { being, stability, } \\
\text { and cohesiveness } \\
\text { Availability of role } \\
\text { models } \\
\text { Healthy economy } \\
\text { Strong informal } \\
\text { social support } \\
\text { networks }\end{array}$ & $\begin{array}{l}\text { Family-Centered Intervention: } \\
\text { Behavioral parenting and social- } \\
\text { skills training using modeling, } \\
\text { positive reinforcement, and short- } \\
\text { term, concrete goals } \\
\text { Decrease parental aggression and/or } \\
\text { hostility } \\
\text { Increase positive parent-child inter- } \\
\text { action/attachment } \\
\text { Child-Centered Interventions: } \\
\text { Therapeutic educational and social } \\
\text { services on school entry (thera- } \\
\text { peutic day care, preschool } \\
\text { programs to enhance school } \\
\text { readiness) } \\
\text { Promote social competence (self- } \\
\text { control, communication, problem- } \\
\text { solving and resistance to negative } \\
\text { social influences) } \\
\text { Promote child and family social } \\
\text { support } \\
\text { Psychotherapy and/or out-of-home } \\
\text { placement when trauma has oc- } \\
\text { curred or abuse or neglect is } \\
\text { severe }\end{array}$ \\
\hline $\begin{array}{l}\text { Being a firstborn } \\
\text { child } \\
\text { Good social and } \\
\text { problem- } \\
\text { solving skills } \\
\text { Positive attitude, } \\
\text { optimistic } \\
\text { about future } \\
\text { Easy temperament } \\
\text { High IQ } \\
\text { Low childhood } \\
\text { stress }\end{array}$ & $\begin{array}{l}\text { Small family size } \\
\text { Low parental } \\
\text { conflict } \\
\text { Positive relation- } \\
\text { ships with siblings } \\
\text { Attachment to } \\
\text { parents }\end{array}$ & $\begin{array}{l}\text { Social support from } \\
\text { outside family } \\
\text { Access to alternative } \\
\text { activities (mid- } \\
\text { night basketball, } \\
\text { nonalcoholic } \\
\text { dances) } \\
\text { Well-delineated } \\
\text { community } \\
\text { Positive social } \\
\text { norms and values }\end{array}$ & $\begin{array}{l}\text { Identify risk and protective factors } \\
\text { most prevalent in local community; } \\
\text { target those risk factors } \\
\text { Early childhood and elementary school } \\
\text { children should be targeted to pre- } \\
\text { vent adolescent drug and alcohol } \\
\text { problems } \\
\text { Tailor prevention-intervention efforts } \\
\text { to developmental stages (4-6 years } \\
\text { old, focus on aggressive behavior; in } \\
\text { adolescence, focus on peer pressure } \\
\text { from antisocial peers) } \\
\text { Consider racial and ethnic differences } \\
\text { in prevention-intervention planning }\end{array}$ \\
\hline
\end{tabular}


Table 1 (continued)

\begin{tabular}{|c|c|c|c|}
\hline \multirow[b]{2}{*}{ Problem Area } & \multicolumn{3}{|c|}{ RISK FACTORS } \\
\hline & Individual & Family & Environmental \\
\hline $\begin{array}{l}\text { Adolescent } \\
\text { pregnancy }\end{array}$ & $\begin{array}{l}\text { Younger age at pu- } \\
\text { berty, earlier sexual } \\
\text { activity (under 14) } \\
\text { Substance use } \\
\text { Sexual-abuse history } \\
\text { Low school- } \\
\text { commitment } \\
\text { Hopelessness about } \\
\text { future } \\
\text { Lack of contraceptive } \\
\text { knowledge }\end{array}$ & $\begin{array}{l}\text { Single-parent family } \\
\text { Chaotic family } \\
\text { atmosphere } \\
\text { Family poverty } \\
\text { Family has permissive } \\
\text { sexual attitudes } \\
\text { Lack of family support } \\
\text { Sibling is sexually } \\
\text { active or is teen } \\
\text { mother }\end{array}$ & $\begin{array}{l}\text { Neighborhood poverty } \\
\text { Inadequate social wel- } \\
\text { fare, health, and } \\
\text { educational system } \\
\text { for adolescents }\end{array}$ \\
\hline $\begin{array}{l}\text { Sexually } \\
\text { transmitted } \\
\text { infections }\end{array}$ & $\begin{array}{l}\text { Early puberty } \\
\text { Substance abuse } \\
\text { Poor impulse control } \\
\text { Sexual abuse history } \\
\text { Low self-efficacy } \\
\text { Poor communication } \\
\quad \text { skills } \\
\text { Lack of knowledge } \\
\quad \text { concerning sex } \\
\text { Sense of } \\
\quad \text { invulnerability }\end{array}$ & $\begin{array}{l}\text { Poor communication } \\
\text { with parents } \\
\text { Parental substance } \\
\text { abuse } \\
\text { Ineffective adult } \\
\text { supervision } \\
\text { Older siblings who are } \\
\text { sexually active }\end{array}$ & $\begin{array}{l}\text { Violence, substance } \\
\text { abuse, poverty in } \\
\text { neighborhood } \\
\text { Norms that accept } \\
\text { early sexual activity } \\
\text { Lack of effective sex } \\
\text { education } \\
\text { Peer pressure } \\
\text { Poor access to medical } \\
\text { treatment } \\
\text { Social disorganization }\end{array}$ \\
\hline
\end{tabular}

$\begin{array}{lc}\begin{array}{l}\text { Childhood } \\ \text { disability } \\ \text { (risk and }\end{array} & \begin{array}{c}\text { Specific disability } \\ \text { (some disabilities, }\end{array} \\ \text { protection in } & \text { i.e., motor impair- } \\ \text { subsequent } & \text { ments, are higher } \\ \text { development) } & \text { risk than others) } \\ & \begin{array}{c}\text { Secondary conditions } \\ \text { (physical limita- }\end{array} \\ & \text { tions, stigma) }\end{array}$

Inadequate attachment with primary caregiver (parental anxiety, depression, etc.)

Parental substance use, lack of resources
Poverty

Lack of adequate resources 


\begin{tabular}{|c|c|c|c|}
\hline \multicolumn{3}{|c|}{ Protective Factors } & \multirow[b]{2}{*}{ Prevention-Invervention Focus } \\
\hline Individual & Family & Environmental & \\
\hline $\begin{array}{l}\text { Delaying sex until } \\
\text { over } 18 \\
\text { Lack of drug or } \\
\text { alcohol use } \\
\text { Effective use of } \\
\text { contraceptives } \\
\text { High educational } \\
\text { aspirations } \\
\text { and school } \\
\text { commitment } \\
\text { Optimistic about } \\
\text { future } \\
\text { Religious } \\
\text { affiliation }\end{array}$ & $\begin{array}{l}\text { Two-parent family } \\
\text { Higher socio- } \\
\text { economic status } \\
\text { Higher parent } \\
\text { education } \\
\text { Open family } \\
\text { communication } \\
\text { Close to parents, } \\
\text { especially mother } \\
\text { Effective parental } \\
\text { supervision } \\
\text { Social support from } \\
\text { family }\end{array}$ & $\begin{array}{l}\text { Effective pregnancy } \\
\text { prevention } \\
\text { programs } \\
\text { Access to adoles- } \\
\text { cent health ser- } \\
\text { vices (school- } \\
\text { based clinics) }\end{array}$ & $\begin{array}{l}\text { Multiple preventions-interventions } \\
\text { should be considered for closely } \\
\text { related risk factors } \\
\text { Effective pregnancy prevention pro- } \\
\text { grams - combine teaching of } \\
\text { abstinence with contraception } \\
\text { information and life-skills training. } \\
\text { Community-based programs can be } \\
\text { more effective than school-based } \\
\text { due to stigma } \\
\text { Access to adolescent health services } \\
\text { (school-based clinics, contraceptive } \\
\text { availability) } \\
\text { Occupational training and dropout } \\
\text { prevention for pregnant teens } \\
\text { Strengthen family ties, promote social } \\
\text { support }\end{array}$ \\
\hline $\begin{array}{l}\text { Attending } \\
\text { religious } \\
\text { services } \\
\text { Positive attitude } \\
\text { toward condom } \\
\text { use }\end{array}$ & $\begin{array}{l}\text { Attending } \\
\text { religious services } \\
\text { Positive attitude } \\
\text { toward condom } \\
\text { use }\end{array}$ & $\begin{array}{r}\text { Effective sex } \\
\text { education }\end{array}$ & $\begin{array}{l}\text { Comprehensive approaches using indi- } \\
\text { vidual, family, schools, communities, } \\
\text { etc., are emphasized } \\
\text { Primary prevention focus is to help } \\
\text { postpone sexual activity onset } \\
\text { Combine with drug and alcohol use } \\
\text { prevention efforts, owing to their } \\
\text { interrelated nature } \\
\text { For early intervention (youth are al- } \\
\text { ready sexually active), promote } \\
\text { knowledge of sexually transmitted } \\
\text { diseases, availability of condoms, } \\
\text { relationship context information } \\
\text { (i.e., emotional perspectives) } \\
\text { Treatment: access to health care, } \\
\text { school-based clinics }\end{array}$ \\
\hline $\begin{array}{l}\text { Disorder less } \\
\text { severe } \\
\text { Personal coping } \\
\text { resources to } \\
\text { handle second- } \\
\text { ary conditions } \\
\text { (stigma, com- } \\
\text { munication dif- } \\
\text { ficulties, etc.) }\end{array}$ & $\begin{array}{l}\text { Parents' sense of } \\
\text { efficacy } \\
\text { Secure attachment } \\
\text { to primary care- } \\
\text { giver }\end{array}$ & Access to services & $\begin{array}{l}\text { Enhance access to appropriate services } \\
\text { Integrate family concerns and parental } \\
\text { support to enhance caregiver self- } \\
\text { efficacy and ability to foster child's } \\
\text { development } \\
\text { Coordinate services to reduce family } \\
\text { stress } \\
\text { Community-based services that "nor- } \\
\text { malize" child's environment are } \\
\text { emphasized }\end{array}$ \\
\hline
\end{tabular}


Table 1(continued)

\begin{tabular}{|c|c|c|c|}
\hline \multirow[b]{2}{*}{ Problem Area } & \multicolumn{3}{|c|}{ Risk FACTORS } \\
\hline & Individual & Family & Environmental \\
\hline $\begin{array}{l}\text { Childhood } \\
\text { depression }\end{array}$ & $\begin{array}{l}\text { Low academic } \\
\text { performance } \\
\text { (concomitant with } \\
\text { anhedonia and low } \\
\text { concentration) } \\
\text { Neurobiological vul- } \\
\text { nerabilities (norepi- } \\
\text { nephrine, serotonin } \\
\text { irregularities) } \\
\text { Chronic illness } \\
\text { Negative perceptual } \\
\text { cognitive styles } \\
\text { In ethnic cohorts, lim- } \\
\text { ited ability to speak } \\
\text { English }\end{array}$ & $\begin{array}{l}\text { Less cohesive, more } \\
\text { disorganized, emo- } \\
\text { tionally inexpres- } \\
\text { sive, hostile or } \\
\text { critical family } \\
\text { environment } \\
\text { Divorce (especially in } \\
\text { cases with high con- } \\
\text { flict afterward) } \\
\text { Parental depression } \\
\text { History of abuse or } \\
\text { neglect }\end{array}$ & $\begin{array}{l}\text { Lower SES (equivocal } \\
\text { association) } \\
\text { Single parent and low } \\
\text { SES (stronger } \\
\text { association) } \\
\text { Neighborhood } \\
\text { violence }\end{array}$ \\
\hline $\begin{array}{l}\text { Delinquency } \\
\text { and conduct } \\
\text { disorder }\end{array}$ & $\begin{array}{l}\text { Academic failure in } \\
\text { elementary school } \\
\text { (around grade 4) } \\
\text { Low commitment to } \\
\text { school } \\
\text { Aggressive behavior or } \\
\text { temper tantrums in } \\
\text { early childhood } \\
\text { Associations with } \\
\text { delinquent peers } \\
\text { Having personal atti- } \\
\text { tudes or beliefs } \\
\text { favoring deviant } \\
\text { behavior } \\
\text { ADHD } \\
\text { Low IQ } \\
\text { Difficult temperament }\end{array}$ & $\begin{array}{l}\text { Family management } \\
\text { problems } \\
\text { Family or marital } \\
\text { conflict } \\
\text { Family history of high- } \\
\text { risk behavior } \\
\text { Inappropriate } \\
\text { parental modeling } \\
\text { Poor parental } \\
\text { supervision } \\
\text { Lack of parental } \\
\text { involvement } \\
\text { Abusive discipline }\end{array}$ & $\begin{array}{l}\text { Antisocial community } \\
\text { norms } \\
\text { Chronic violence } \\
\text { Poverty } \\
\text { High population } \\
\text { density } \\
\text { High residential } \\
\text { mobility } \\
\text { Low community } \\
\text { organization or } \\
\text { attachment }\end{array}$ \\
\hline
\end{tabular}

for program planners. ${ }^{26}$ It also incorporates evaluation methods throughout the entire process, making this a well-balanced model for resiliencebased practice. Specific program elements for resilience-based practice are outlined below.

\section{Resilience-Based Program Development}

Defining the problem is a first step in determining those mediators that can be modified. Whether positive or negative, mediators are inter- 


\begin{tabular}{|c|c|c|c|}
\hline \multicolumn{3}{|c|}{ Protective Factors } & \multirow[b]{2}{*}{ Prevention-Invervention Focus } \\
\hline Individual & Family & Environmental & \\
\hline $\begin{array}{l}\text { Being male rather } \\
\text { than female } \\
\text { Being older (over } \\
11 \text { years old) } \\
\text { at first onset }\end{array}$ & $\begin{array}{l}\text { Family support } \\
\text { Parental education, } \\
\text { employment, and } \\
\text { health } \\
\text { Adequate treatment } \\
\text { for parental } \\
\text { depression }\end{array}$ & $\begin{array}{l}\text { Research knowl- } \\
\text { edge too limited } \\
\text { to specify } \\
\text { Social support out- } \\
\text { side the family }\end{array}$ & $\begin{array}{l}\text { Realize childhood depression is a bio- } \\
\text { logical predisposition influenced by } \\
\text { contextual risks } \\
\text { Decrease environmental risk factors, } \\
\text { especially for low-income children } \\
\text { Provide access to adequate mental } \\
\text { health services, especially to treat pa- } \\
\text { rental depression (the most salient } \\
\text { risk factor in childhood depression) } \\
\text { Skills training for management of } \\
\text { emotions } \\
\text { Screen for comorbid conditions } \\
\text { (conduct disorder, ADHD, sub- } \\
\text { stance abuse, anxiety disorders) } \\
\text { Cognitive-behavioral group treatment, } \\
\text { integrating parents as well as chil- } \\
\text { dren or teenagers has shown some } \\
\text { signs of treatment effectiveness. }\end{array}$ \\
\hline $\begin{array}{l}\text { Being female } \\
\text { rather than male } \\
\text { Commitment to } \\
\text { school } \\
\text { Positive social ori- } \\
\text { entation (i.e., } \\
\text { easy temper } \\
\text { and enjoys so- } \\
\text { cial interaction) } \\
\text { Positive social sup- } \\
\text { port system or } \\
\text { peer group that } \\
\text { supports coping } \\
\text { efforts } \\
\text { Self-discipline } \\
\text { Developed social } \\
\text { and problem- } \\
\text { solving skills } \\
\text { Academic success } \\
\text { Moderate } \\
\text { intelligence }\end{array}$ & $\begin{array}{l}\text { Supportive family } \\
\text { atmosphere } \\
\text { Strong attachment } \\
\text { to a parent } \\
\text { Commitment to } \\
\text { family } \\
\text { Effective parental } \\
\text { supervision } \\
\text { High degrees of } \\
\text { parental } \\
\text { involvement } \\
\text { Appropriate, posi- } \\
\text { tive social paren- } \\
\text { tal modeling }\end{array}$ & $\begin{array}{l}\text { Community } \\
\text { organization } \\
\text { and attachment } \\
\text { Positive social rec- } \\
\text { reational and } \\
\text { support struc- } \\
\text { tures and services } \\
\text { (i.e., community } \\
\text { centers, orga- } \\
\text { nized activities) }\end{array}$ & $\begin{array}{l}\text { Parenting skills and social skills } \\
\text { training } \\
\text { Intensive family preservation services } \\
\text { and family management training to } \\
\text { enhance parent-child interaction } \\
\text { and decrease family conflict } \\
\text { Anger management, problem solving, } \\
\text { conflict resolution, and peer media- } \\
\text { tion skills training } \\
\text { Increase opportunities for achieve- } \\
\text { ment and bonding to school } \\
\text { Behavioral monitoring, school atten- } \\
\text { dance reinforcement, and gradua- } \\
\text { tion incentives have shown some } \\
\text { effectiveness } \\
\text { Firearms regulation and community } \\
\text { block watch initiatives } \\
\text { Promotion of positive social norms at } \\
\text { all levels }\end{array}$ \\
\hline
\end{tabular}

Note. - Information for this table was largely derived from chapters in M. W. Fraser, ed., Risk and Resilience in Childhood: An Ecological Perspective (Washington, D.C.: National Association of Social Work Press, 1997). $\mathrm{SES}=$ socioeconomic status; ADHD = attention deficit, hyperactivity disorder.

mediary variables that modulate the effects of two other variables: the antecedent or independent variable and the outcome. ${ }^{27}$ For instance, family-system attributes are said to mediate or regulate the effect of neighborhood risk factors on childhood adaptation. Successfully targeting modifiable mediators to guide intervention requires extensive use of empirical findings on risk and protective factors, knowledge of the cause of the unwanted outcome, and a local as well as global understanding of the target population. Contextual characteristics that have been found to be protective, such as family cohesion, warmth, and supportive par- 
enting, are examples of possible intervention targets for parenting skills, parent-child relationship programs, or family therapy. ${ }^{28}$ In using information on vulnerability and protection for intervention planning, it is critical to recognize differences across subgroups based on gender, ethnicity, and developmental stage. ${ }^{29}$

Designing prevention-program protocol consists of several steps. Consulting the targeted group to assess unique needs, strengths, and concerns within the local community is an important foundation. Prevention programs often find it difficult to recruit and retain appropriate participants. To avoid these difficulties, determining group needs and resources early, through qualitative methods such as interviews and focus group sessions, is an effective screening method. ${ }^{30}$ Such client consultation also serves as an informal test of the potential modifiable mediators noted during the problem-identification stage and can inform subsequent work in selecting change objectives. Early needs and strengths assessments also aid in appropriate program targeting by providing information about risk status within the local community. Knowing local risk factors guides decisions concerning how to allocate services while knowing community strengths guides selection of change strategies. Selecting change objectives is a dynamic process that fuses empirical theories with participants' needs and requests. Resilience-based program goals are also usually conceptualized in positive, attainable terms. Deficit-driven problem perspectives, for instance, seek to decrease teen delinquency whereas resilience-based prevention efforts seek to increase positive social activities for adolescents. This increase in positive social behavior is then thought to indirectly affect delinquent behavior.

Choosing change methods is best guided by theoretical, empirical, and practice knowledge. For instance, social-learning perspectives might be an effective model for constructing a skills-training package that addresses problem-solving for middle-school students facing peer pressure surrounding alcohol use. ${ }^{31}$ The risk factors of concern may be low parental supervision and negative peer behaviors. The targeted protective factor to enhance may be cognitive problem-solving ability or self-efficacy. Consequently, a prevention package might be adopted using a skillstraining approach in which interpersonal skills are modeled and practiced first in nonthreatening situations and subsequently in simulations that closely approximate natural conditions. Packages such as this are quite common and are supported with a wealth of empirical literature documenting differing effectiveness. ${ }^{32}$

Following the design stage, fledgling programs are pilot-tested. Content, feasibility, and potential outcome can be crudely gauged using process and formative evaluation strategies. Evaluation is invaluable at this juncture; it provides data on how accurately program content is being implemented. Evaluation also forges a feedback loop between program designers and participants. Finally, after appropriate revisions, 
full-scale implementation and outcome evaluation can take place. The product of implementation and outcome evaluation is a refined program or intervention package with demonstrated effectiveness, ready for dissemination. ${ }^{33}$

To summarize, resilience-based program development integrates empirical knowledge concerning risk and protective factors during several stages of prevention and intervention planning. A thorough conceptualization of processes that promote or inhibit the behaviors under consideration aids intervention targeting. Designating these modifiable mediators helps clarify appropriate intervention goals and guides the selection of strategies for initiating change. Finally, process, formative, and outcome evaluations illuminate how well the program conceptualization and implementation performed when actually applied. These evaluations form an important feedback loop, which further clarifies how empirical knowledge of risk and protective factors can be used in prevention programs. Similarly, substantive knowledge concerning risk and protective processes will further develop from interventions that attempt to initiate environmental and individual change.

This last point leads to the next section of this article. Reviewing current prevention and intervention programs provides us with an indication of how amenable selected risk situations are to change. It also illustrates how effective our prevention initiatives have been in mobilizing protective processes for promoting positive adaptation.

\section{Early Childhood Programs}

A number of resilience-based programs founded in prevention exist, and I will consider several for varying age groups. The programs outlined below hold particular promise for incorporating resilience perspectives.

Recent years have brought a growing commitment to national dissemination of early childhood programs largely due to impressive research findings that show lasting, positive gains in behavioral and social functioning for children in high-quality programs. ${ }^{34}$ In a metanalysis of over 300 studies on the efficacy of early childhood intervention, Karl White concluded that there is strong support for the immediate positive effects of intervention and emerging support for long-term benefits. ${ }^{35}$ His best estimate for the immediate strength of program effects is approximately one-half of a standard deviation. Measurements of IQ gain about eight points, and reading achievement is enhanced by about 10 months at the second-grade level. This estimate is higher than the .24.41 range of effect sizes reported in Mark Lipsey and David Wilson's "metanalysis of metanalyses"; however, White considered a broader range of studies ${ }^{36}$ Further, Lipsey and Wilson did not break down their reported effect sizes by postprogram measurement intervals. When White considered the stability over time of impact estimates, he found immediate ef- 
fects deteriorating into, and later even below, the .24-.41 range Lipsey and Wilson reported.

This deterioration of intervention effects has been a controversial issue in the early intervention field. Empirical investigations of small, model programs versus national Head Start initiatives often yield conflicting evidence for and against the long-term benefits of early childhood interventions for disadvantaged children. Lesser-quality programs often do not yield the positive effects that high-quality programs do. ${ }^{37}$ Weissberg and Greenberg summarize the "active ingredients" of effective programs: "The lasting benefits of early childhood education have been achieved only by high-quality programs characterized by a developmentally appropriate curriculum based on child-related activities, teaching teams that are knowledgeable in early childhood development and receiving ongoing training and supervision, class size limited to fewer than twenty 3- to 5-year-olds with at least two teachers, administrative leadership that includes support of the program, systematic efforts to improve parents as partners in their child's education, as well as sensitivity to the noneducational needs of the child and family, and evaluation procedures that are developmentally appropriate." 38

This list includes several important potential protective factors. Smaller class size enables teachers to have more individualized contact with children in the class. This personal attention from a caring adult is one of the most powerful protective mechanisms for early childhood development. Improving parents' roles as partners in learning enhances parentchild communication and attachment, two more potent protective mechanisms. Launching high-quality programs with administrative support and knowledgeable teachers shows an investment in children that may enhance their sense of importance and self-esteem. Finally, multicomponent interventions that address the noneducational needs of the child and family enhance access to resources (a protective factor) and are more able to affect protective mechanisms on several ecological levels (i.e., in the family, community, and school).

A brief overview of selected interventions and the variations among them follow.

\section{High/Scope Perry Preschool Program}

The High/Scope Perry Preschool Program is one of the most well known, successful prevention programs for 3- and 4-year-old black children. Participants attended 90-minute classes five times a week for 7 months a year for 2 years. Child-initiated learning activities that promoted cognitive, physical, and social development were supervised by well-trained teachers at a child-teacher ratio of approximately six-to-one. This was supplemented by weekly 90 -minute teacher home visits that integrated parent involvement into the intervention package. 
Evaluators randomly assigned 58 children to preschool intervention and 65 children to a control group, following all of them until age 27 . By age 19, Perry participants were more literate, showed more commitment to schooling, had higher academic achievement, less special education, were more competent in daily life skills, had better jobs, higher earnings, less unemployment, less public assistance use, fewer pregnancies, and fewer criminal offenses than the control group. ${ }^{39}$ At age 27, Perry students had higher high school graduation rates $(67 \%$ vs. $49 \%$ in the control group), lower lifetime arrest rates (31\% vs. $51 \%$ in the control group), higher monthly earnings, more home ownership, and lower rates of public assistance use ( $15 \%$ vs. $32 \%$ in the control group). Costbenefit analyses for this program were also impressive, showing that program costs of $\$ 12,356$ per family yielded benefits of $\$ 108,002$ per family.

Although this was a model program with a small research sample, Perry findings were impressive enough to maintain Head Start funding in the 1970s, and the findings have often been held up as exemplary within the early intervention field. They also have been the source of the public's overly high expectations for early intervention efforts. ${ }^{40}$

\section{Head Start}

In Head Start, one of the nation's most widely implemented prevention programs, results have been mixed; cognitive and academic gains made by program participants in preschool and kindergarten often decline in the elementary school years. ${ }^{41}$ Valerie Lee, Jeanne Brooks-Gunn, and Elizabeth Schnur found that Head Start children maintain substantive gains over children without preschool experience. ${ }^{42}$ However, these effects were not as large as they were immediately after intervention and may have been the result of having access to preschool rather than Head Start. Although often criticized for lack of long-term academic gains, Head Start program planners were not originally targeting scholastic performance; rather, they were interested in social competence and comprehensive health services. ${ }^{43}$ In these areas, evaluations have been somewhat more optimistic. Long-term, improved health benefits were found through age 12 in Head Start participants. ${ }^{44}$ Some studies also found improvements during the course of the program on social adjustment, interpersonal relationships, leadership, self-confidence, and emotional maturity, but methodological weaknesses warrant caution in interpreting these findings. ${ }^{45}$

Little adequate evaluation and few longitudinal investigations have been done on large-scale programs such as Head Start even though the programs differ significantly in design, resources, and implementation from small-scale, model programs. The Consortium for Longitudinal Studies, which is highly esteemed for its rigorous investigations of both model and large federally funded early intervention programs, has 
found early intervention effects to decline from .35 in kindergarten to .30 in grade 3 and .24 by grade $6 .{ }^{46}$

\section{The Chicago Longitudinal Study}

The Chicago Longitudinal Study of the Child Parent Centers (CPC) is a large, federally funded early intervention program for low-income children and their parents. The centers provide comprehensive services, require parent participation, and implement child-centered approaches to social and cognitive development for children. Unlike Head Start, which is primarily a preschool program, many CPC programs integrate a component that involves children and parents in center activities through the early primary-grade years.

For the past 12 years, the Chicago Longitudinal Study has followed a sample of 1,539 children in the Chicago Public Schools to evaluate the effects of Chicago's CPC program. The study's intervention group includes all children who enrolled beginning in fall 1983 and who completed kindergarten in spring $1986(N=1,150)$ in Chicago's 20 CPCs that had preschool and kindergarten programs. Beginning preschool at age 3 or 4 , children could participate at some centers until the end of third grade, or until approximately age 9 (spring 1989). Children participated in the preschool, kindergarten, and follow-up intervention for varying lengths of time, resulting in natural groupings of participants with diverse levels of program exposure (1-6 years). This has enabled evaluators to explore intervention timing and duration. A comparison group $(N=$ 389) of children with no systematic intervention between preschool and third grade was added for analysis. The total sample of 1,539 children represents 25 schools within the Chicago Public Schools. ${ }^{47}$

Using a variety of modeling methods, Arthur Reynolds and Judy Temple found CPC program-effect sizes ranged from .57 to .58 in kindergarten and from .28 to .30 in grade $6{ }^{48}$ In another study, grade 6 follow-up effect sizes were in the $.36-.38$ range for reading achievement and .33-.36 for math achievement. ${ }^{49}$ By grades 5 and 8 , a dosage-response relationship was found. Having more than 4 years of intervention experience, regardless of when intervention began, had significantly greater effect on school achievement, special education placement, and grade retention. In eighth grade, participants who experienced the full intervention (6 years) had half the grade retention rate of 4-year participants and one-third the rate of control group children.$^{50}$ These findings have helped underscore how follow-through program components can be critical to maintaining initial intervention success. ${ }^{51}$

\section{Modifiable Mediators}

Using the risk and resilience paradigm, it is straightforward to identify early poverty or disadvantage as the initial problem driving these pro- 
grams. As a risk factor, family poverty is commonly related to school failure, child maltreatment, depression, delinquency, and a spectrum of other negative developmental outcomes. ${ }^{52}$ Mapping those mediators that may be modified and activating protective factors, however, is much less forthright. Theoretically, there are four major hypothetical pathways for effective early intervention. First, the cognitive advantage hypothesis emphasizes early cognitive development (especially systematic language activities), which leads to greater school readiness, smooth kindergarten transition, and, later, improved scholastic achievement. This improved school readiness may lead to the formation of a resilience string of competence or self-efficacy-building experiences. Specifically, improved school preparation fosters positive teacher reinforcement that, in turn, adds to student self-esteem, motivation, school commitment, and perhaps academic performance in later grades. This string of school successes subsequently forms a protective factor, preventing delinquency and behavioral problems. ${ }^{53}$

Alternatively, the family support hypothesis says that enhanced family functioning (such as increased parental involvement) leads to later adjustment. Home visiting or parent resource rooms in many preschool programs, for example, may increase parents' skills, vigilance, and efficacy in socialization activities for their children. Parent-child attachment and family functioning may also be affected. This enhanced involvement and attachment then becomes a strong protective factor insulating children against a range of negative outcomes. ${ }^{54}$

The social adjustment hypothesis suggests that enhanced social development (such as positive social relations in school) leads to subsequent social adaptation and protects against negative outcomes through enhanced social skills and positive social support networks. Finally, the motivational advantage hypothesis emphasizes that perceived competence and improved self-concept lead to later emotional adjustment, which is yet another important protective factor.

In one of several theory-driven evaluation investigations on the Chicago CPC program, Reynolds found the cognitive advantage and family support hypotheses working in tandem. ${ }^{55}$ This dual focus on both children and their socialization environments has similarly been noted by other authors, and integrating family-support components with cognitive-enrichment components finds support in the literature. ${ }^{56}$

To summarize, early childhood programs are a useful example of resilience-based practice. These programs typically try to break the risk chain associated with childhood disadvantage. Childhood poverty is often associated with parental distress, low parental educational attainment, parental unemployment, larger family size, poor nutrition, and decreased access to resources such as appropriate health care. All these risk factors, and others, lead to an accumulation of stressors (often called "pileup") in the lives of disadvantaged children. This risk chain subse- 
quently leads to decreased educational achievement and increased behavioral problems.

Early childhood programs attempt to disrupt this risk chain using several strategic modifiable mediators or active program ingredients. Small class sizes with intensive support by a caring, knowledgeable instructor who is teaching a developmentally appropriate curriculum leads to enhanced school readiness and gains in elementary school academic achievement. Integrating parent involvement enhances parent-child interaction, family support, and, at times, access to resources. This effort breeds a more positive family environment and more family time invested in educational endeavors. Both of these protective factors subsequently aid the child's social and academic experiences in school. Finally, providing disadvantaged children with positive social experiences early on enhances their social skills and emotional well-being, two more protective factors that prove very useful in buffering stress later in life. Evaluations of early childhood programs like those surveyed above have demonstrated impressive short-term and emerging long-term success in supplanting risk chains with resilience strings, mobilizing useful protective factors, and fostering positive childhood adaptation.

\section{Elementary School Programs}

While early childhood programs try to disrupt the risk chain associated with poverty, elementary school programs attempt to "inoculate" children against impending potential risk situations before they arise. A formidable array of prevention and competence-promoting programs have been devised and implemented in schools to deal with health and sex education, substance abuse, delinquency, violence, teen pregnancy, and many other social problems. ${ }^{57}$ With such diversity, synthesizing fragmentary efforts into coherent, comprehensive packages remains a central challenge for school personnel, researchers, evaluators, and program designers. ${ }^{58}$ Schools are an opportune setting for programs because they have consistent contact with children during developmentally critical times and can initiate social, behavioral, and physical interventions. ${ }^{59}$ Further, schools offer several critical protective mechanisms, such as positive role modeling from caring adults, academic and social skills acquisition opportunities, social support, and the dissemination of positive social values. ${ }^{60}$ Conversely, school failure is a significant risk factor for a range of negative developmental outcomes. ${ }^{61}$

The plethora of prevention programs has not spurred a concomitant expansion in the evaluation literature. Many programs are adopted based on marketing and convenience rather than on empirical documentation, comprehensive scope, and theoretical rigor. ${ }^{62}$ For example, drug abuse education, one of the most critical areas for prevention efforts, has many intervention packages, of which the Drug Abuse Resistance Education (DARE) program predominates. Although it is one of 
the few programs to have been evaluated, little evidence exists for its effectiveness. The program remains less effective than preventions that emphasize peer-interaction teaching strategies and social skills development, yet it continues to be widely used. ${ }^{63}$ In general, research indicates that knowledge-only interventions (such as DARE) have a minimal lasting effect on behavioral change ${ }^{64}$ Alternatively, teaching widely applicable competence strategies in stress management, communication, problem-solving, assertiveness, peer pressure tolerance, and sociability has shown signs of effectively fostering competence. ${ }^{65}$

David Dupper and Curtis Krishef describe the effects of a school-based social-cognitive-skills training program for sixth through seventh graders. ${ }^{66}$ Among the 35 participants randomly assigned to treatment or control groups, there were significant differences on locus of control and self-control measures from pretest to posttest for the treatment group members. The two treatment conditions, however, did not show significant differences when compared with each other at posttest, which may be an artifact of the small sample size. This is a common problem in small intervention research.

In a group program targeted at reducing aggression in young adolescents, John Lochman, William Nelson, and Joseph Sims used group discussion, modeling, behavioral rehearsal, problem-solving elements, and cognitive coping during problem situations. ${ }^{67}$ In a later, randomized trial of 76 fourth- to sixth-grade program participants, Lochman and colleagues found that cognitive-behavioral training conditions led to more reductions in aggressive behavior in the classroom than found in the control group. ${ }^{68}$ Parents also noted similar improvements in the home for intervention youth. Cognitive-behavioral group participants also demonstrated significant increases in self-esteem. ${ }^{69}$

The effects of these skills packages alone, however, will show limited benefits unless they are combined with environmental change strategies that marshal support and reinforcement at varying levels, such as from family, teachers, peers, and important community members. ${ }^{70}$ Consequently, there have been calls for comprehensive, ecological, well-integrated, empirically based prevention interventions of sufficient scope and length to produce lasting, positive behavioral change. ${ }^{71}$ Programs promoting individual social competence in this way are briefly surveyed below.

\section{Promoting Alternative Thinking Strategies}

Promoting Alternative Thinking Strategies (PATHS) is an elementary school curriculum for promoting problem-solving, self-control, and emotional awareness. Coping strategies are taught, rehearsed, and generalized through a range of classroom applications throughout the day. Randomized pretest and posttest clinical trials with a sample of 3007 and 8-year-olds show significant improvement for intervention children 
in social problem-solving and emotional understanding. Significantly, more social planning, less impulsiveness, fewer behavioral conduct problems, and fewer reports of depression all remained at 1- and 2-year follow-up assessments.

A multiyear, long-term application of the PATHS program called Fast Track is currently underway. Fast Track bolsters the PATHS curriculum with additional ecological interventions such as parenting-skills training, academic tutoring, peer group skills training, and school and community integration. Initial evaluations show little evidence for the amelioration of conduct problems but demonstrate strong evidence for improved cognitive, social, and academic skills, increased parental perceptions of warmth with decreased disciplinary behavior at school, and enhanced social ratings from peers. ${ }^{72}$ It is hoped that this early construction of ecological protective factors, continued throughout middle school, will lessen antisocial behavior later on.

\section{Midwestern Prevention Project}

The Midwestern Prevention Project is a multilevel, multicomponent prevention intervention package for decreasing substance abuse. The ecological curriculum consists of 10 sessions of peer resistance training, media programming, community organization, and extragroup homework tasks of interviewing family about substance use issues. Evaluation revealed significant decreases in alcohol and substance use for a sample of 22,500 sixth- and seventh-grade participants. ${ }^{73}$ Program effects were maintained at 3-year follow-up for both high- and low-risk children.

\section{Modifiable Mediators}

Individual-level skills promotion packages attempt to enhance competencies by building up resilience factors. ${ }^{74}$ Interpersonal, problemsolving, cognitive, affective coping, and self-management skills are often the targets for behavioral augmentation. ${ }^{75}$ All of these skills are aimed either directly or indirectly at preventing or coping with specific problematic risk situations. Mastery of these skills is thought to advance the attainment of positive social goals and foster other protective factors, such as self-esteem, self-efficacy, or supportive social networks, that are threads in the resilience string. Programs successful at decreasing highrisk behaviors tend to be empirically based, theory driven, and accentuate both generic and problem-specific skills and protective mechanisms. Providing accurate information is heavily supplemented with cognitiveaffective behavioral skills, which promote active participation and leadership. Extensive, multiyear, ecological programs firmly based in schools and community settings with follow-up support are also thought to be more beneficial than brief, more limited programs. ${ }^{76}$

Early childhood and elementary school prevention efforts illustrate di- 
verse strategies for approaching risk and mobilizing protective factors. Early childhood programs disrupt the poverty risk-chain by encouraging strong relationships with teachers and parents, enhancing access to resources, and providing early cognitive stimulation (the literal "head start"). Elementary school programs address specific risk situations such as being offered drugs or being pressured to skip school, drink, or have sexual intercourse. Individual skills acquisition is the primary focus for inoculating elementary school children against imminent risk situations. Substantive knowledge paired with interpersonal assertiveness are protective factors that function more effectively together than either does alone when youth are faced with risk-laden choices.

Finally, early childhood and elementary school programs that mobilize a variety of protective factors (i.e., individual skills, positive interpersonal relationships, self-esteem, access to resources) on diverse ecological levels (i.e., family, school, community) are clearly more effective than those that are more limited in scope. Similarly, programs need sufficient duration and resources to have a substantial effect. With adequate investment and rigorous program design, prevention efforts provide strong indications that modifiable mediators can be effectively manipulated. Protective factors can strategically be put into place and risk can be reduced or circumvented.

\section{Research Issues in Resilience-Based Prevention}

Resilience-based prevention and competence promotion presents complex challenges to prospective practitioners and program designers. Just as this new perspective lies at the juncture of several theoretical disciplines (developmental psychopathology, stress and coping, epidemiology, and systems frameworks) and applied areas (prevention- and intervention-services programming), so too do salient methodological issues from diverse domains converge.

The resilience-based practice model centers around mobilizing key protective factors that buffer the individual or family against stress and risk. Although important advances in identifying critical generic and problem-specific protection mechanisms have been made, more research is needed in delineating specific protective mechanisms for specific risk situations. ${ }^{77}$ The complex interplay between and among ecological levels of influence is just beginning to win a prominent place in empirical investigations. Our understanding of indirect risk mechanisms, for instance, in terms of the more relevant direct processes that mediate their effects, is now beginning to develop. ${ }^{78}$ The corresponding search for diverse, problem-specific, multilevel protective mechanisms will provide strong tools for resilience-based practice.

Many prevention programs have been criticized for not having firm theoretical and empirical foundations or rigorous evaluations and for 
being based more on feelings than on facts. Prevention as a scientific enterprise as well as a service mission is just beginning to be developed. ${ }^{79}$ As the intervention component in resilience-based practice, prevention and competence-promotion programs have several methodological challenges to resolve. Prevention programs need to focus more on their theoretical and empirical roots from conception through dissemination. Program conception and design based on emotion rather than fact is understandably compassionate but not highly effective. With important exceptions, such as the High/Scope Perry Preschool Program and the Chicago Longitudinal Study, few longitudinal studies of comprehensive, ecological intervention programs have been undertaken. This is especially true for elementary school prevention programs, which tend to be more idiosyncratic and less standardized than preschool initiatives.

To understand better the effect of variation in models, curricula, intervention, training, and other program elements, it is necessary to apply more stringent program evaluation methods in each phase of prevention program development. ${ }^{80}$ This will enable the effect of variations in models, curricula, intervention timing and duration, staff training, and active program ingredients to be more closely examined and better understood. Process or formative evaluations in particular have been neglected, leaving disturbing questions concerning implementation integrity unanswered. In the concluding comments of his metanalysis, White wrote, "Another serious problem with previous research is that virtually all the existing early-intervention efficacy research has failed to determine the extent to which the intended treatment was actually implemented." ${ }^{81}$ This is a critical point that potentially undermines all of the previous efforts to estimate program effects. As Donald Campbell writes, "In program evaluation, the details of program implementation history, the site specific wisdom and the gossip about where the bodies are buried are all essential to interpreting the quantitative data. . . . We need situation-specific wisdom. The lack of this knowledge (whether it be called ethnography, or program history, or gossip) makes us incompetent estimators of program impacts." 82 This lack of documentation concerning implementation integrity was prevalent in both preschool and elementary school prevention efforts. Not recognizing this can lead to what Diane Dobson and Thomas Cook call "type III errors," or evaluating interventions that one assumes were implemented properly when they were actually inappropriately carried out or were never truly implemented. ${ }^{83}$

Similar to the need for formative evaluation, collecting and integrating a variety of data can inform program design and revision decisions. The qualitative information from focus groups and interviews provides important input into the selection and revision of change methods, recruitment and retention strategies, and program effects from the consumer's perspective. ${ }^{84}$ 
A controversy exists in the program-evaluation literature concerning the use of quasi-experimental designs with nonrandomized comparison control groups. Researchers who view prevention as a science consider the randomized clinical trial as the "gold standard" of effectiveness research, claiming bias results with any less rigorous design. ${ }^{85}$ However, others cite the impractical, even unethical, side of randomized trials and support quasi-experimental and alternative evaluation methods. ${ }^{86}$ Still others have attempted to directly compare the two approaches and have found no large differences in program estimates. ${ }^{87}$ Regardless of the camp, consensus and priority converge on the necessity of integrating comparison groups for testing program effectiveness. Comparisons can ultimately be from randomized clinical trials, alternative treatments, nonequivalent control group designs, matched control group designs, created control groups from existing databases, or time-series methods, but some form of comparison group must be used for informative outcome evaluation. ${ }^{88}$ If nonrandomized comparison groups are used, it is critical to delineate initial pretest group differences, or program estimates can be biased downward (the comparison group is more advantaged than the intervention group). This is a greater concern for selected or indicated prevention interventions that target high-risk individuals than for universal prevention efforts that are comprehensive in scope.

Finally, because resilience-based prevention and competence promotion efforts are strongly linked to identifying crucial risk and protective factors, formulating and following an explicit model that delineates how modifying risk and protective mechanisms will promote desired goals is paramount in effective program design.

\section{Conclusion}

The interface between resilience research and applied prevention programming is fertile ground for nurturing a resilience-based prevention practice perspective. These fields have both sufficiently matured to inform each other in a productive collaboration. However, continued development can be greatly enhanced by the increasing sophistication in mapping critical risk and protective processes by problem area, gender, developmental stage, age, and ethnicity. The utility that well-delineated risk and protective processes have for program planners in designing prevention packages should motivate and inspire resilience researchers to go further in their work. Further contributing to the vitality of the new resilience-based prevention science is the theoretical utility and proven practice effectiveness of ecological approaches to program design.

High-quality preschool and elementary school intervention efforts have benefited from multicomponent designs that affect both children and their families. Although there is no single panacea, broad-based prevention programs that teach skills, impart information, and enhance ac- 
cess to resources have made important strides toward ameliorating risk by mobilizing crucial protective mechanisms.

As Hirokazu Yoshikawa concluded, there still remain many important questions concerning how to design effective prevention intervention programs. ${ }^{89}$ Integration of appropriate evaluation techniques at all stages in program development should help in our exploration of these questions. Testing alternative models of active ingredients and mapping out specific modifiable mediators in the form of protective mechanisms are also crucial future undertakings. With these challenges in mind, we can optimistically move forward in our efforts to alleviate risk and promote positive adaptation in our children.

\section{Notes}

Preparation of this article was supported by grants from the National Institute of Child Health and Human Development (R29HD34294), the Office of Educational Research Improvement (306F60055) and the University of Wisconsin-Madison Graduate School.

1. S. Wolin and S. Wolin, "Resilience among Youth Growing Up in Substance-Abusing Families," Pediatric Clinics of North America 42 (1995): 415-29; L. E. Dumka, M. W. Roosa, M. L. Michaels, and K. W. Suh, "Using Research and Theory to Develop Prevention Programs for High Risk Families," Family Relations 44 (1995): 78-86; A. Antonovsky, "The Sense of Coherence: An Historical and Future Perspective," in Sense of Coherence and Resiliency: Stress, Coping and Health, ed. H. I. McCubbin, E. A. Thompson, A. I. Thompson, and J. E. Fromer (Madison: University of Wisconsin Press, 1994).

2. J. K. Nash and M. W. Fraser, "Methods in the Analysis of Risk and Protective Factors: Lessons from Epidemiology," in Risk and Resilience in Childhood: An Ecological Perspective, ed. M. W. Fraser (Washington, D.C.: National Association of Social Workers, 1997), pp. 34-49.

3. B. Benard, Fostering Resiliency in Kids: Protective Factors in the Family, School and Community (Portland, Oreg.: Northwest Regional Educational Laboratory, 1991).

4. Urie Bronfenbrenner, "Ecology of the Family as a Context to Human Development: Research Perspectives," Developmental Psychology 22 (1986): 723-42; Fraser, ed. (n. 2 above); P. Moen, G. H. Elder, and K. Luscher, eds., Examining Lives in Context: Perspectives on the Ecology of Human Development (Washington, D.C.: American Psychological Association, 1995); E. Werner and R. Smith, Vulnerable but Invincible: A Longitudinal Study of Resilient Children and Youth (New York: Adams, Bannister, \& Cox, 1982).

5. L. D. Kirby and M. W. Fraser, "Risk and Resilience in Childhood," in Fraser, ed. (n. 2 above), app. 10-33, quote on p. 11.

6. N. Garmezy, "Children in Poverty: Resilience Despite Risk," Psychiatry 56 (1993): 12736; J. D. Coie, N. F. Watt, S. G. West, J. D. Hawkins, J. R. Asarnow, H. J. Markman, S. L. Ramey, M. B. Shure, and B. Long, "The Science of Prevention: A Conceptual Framework and Some Directions for a National Research Program," American Psychologist 48 (1993): 1013-22.

7. M. Rutter, "Protective Factors in Children's Responses to Stress and Disadvantage," in Primary Prevention of Psychopathology, vol. 3, Social Competence in Children, ed. M. W. Kent and J. E. Rolf (Hanover, N.H.: University Press of New England, 1979), pp. 49-74.

8. M. Rutter, "Psychosocial Resilience and Protective Mechanisms," American Journal of Orthopsychiatry 57, no. 3 (1987): 316-31.

9. R. Seifer, A. J. Sameroff, C. P. Baldwin, and A. Baldwin, "Child and Family Factors That Ameliorate Risk between 4 and 13 Years of Age," Dournal of the American Academy of Child and Adolescent Psychiatry 31 (1992): 893-903.

10. P. R. Smokowski, "Progress and Prospects in Resilience Research" (University of Wisconsin-Madison, 1997).

11. S. Luthar, "Annotation: Methodological and Conceptual Issues in Research on Childhood Resilience," Iournal of Child Psychology and Psychiatry 34, no. 4 (1993): 441-53; Rutter, "Psychosocial Resilience" (n. 8 above). 
12. Fraser, ed. (n. 2 above).

13. S. Luthar and E. Zigler, "Vulnerability and Competence: A Review of Research on Resilience in Childhood," American Journal of Orthopsvchiatry 61, no. 1 (1991): 6-22; Garmezy (n. 6 above); A. Farber and B. Egeland, "Invulnerability among Abused and Neglected Children," in The Invulnerable Child, ed. E. Anthony and B. Cohler (New York: Guilford, 1987), pp. 253-88; Werner and Smith, Vulnerable but Invincible (n. 4 above); E. Werner and R. Smith, Overcoming the Odds: High-Risk Children from Birth to Adulthood (Ithaca, N.Y.: Cornell University Press, 1992).

14. B. J. Cohler, F. M. Stott, and J. S. Musick, "Adversity, Vulnerability and Resilience: Cultural and Developmental Perspectives," in Developmental Psychopathology, vol. 2, Risk, Disorder and Adaptation, ed. D. Cicchetti and D. J. Cohen (New York: Wiley, 1995), pp. $753-800$.

15. A. Masten, "Resilience in Individual Development: Successful Adaptation despite Risk and Adversity," in Educational Resilience in Inner-City America: Challenges and Prospects, ed. M. C. Wang and E. W. Gordon (Hillsdale, N.J.: Erlbaum, 1994), pp. 3-25.

16. M. W. Fraser and M. J. Galinsky, "Towards a Resilience-Based Model of Practice," in Fraser, ed. (n. 2 above), pp. 265-73, quote on p. 268.

17. R. P. Weissberg and M. T. Greenberg, "School and Community CompetenceEnhancement and Prevention Programs," in Handbook of Child Psychology, vol. 5, Child Psychology in Practice, 5th ed., ed. W. Damon, I. E. Sigel, and K. A. Renninger (New York: Wiley, 1997).

18. Masten, "Resilience in Individual Development" (n. 15 above).

19. Coie et al. (n. 6 above).

20. D. S. Elliott, "Health Enhancing and Health Compromising Lifestyles," in Promoting the Health of Adolescents: New Directions for the Twenty-First Century, ed. S. G. Millstein, A. C. Petersen, and E. O. Nightengale (New York: Oxford University Press, 1993), pp. 119-45.

21. John Wodarski and L. A. Wodarski, Curriculums and Practical Aspects of Implementation: Preventive Health Services for Adolescents (Lanham, Md.: University Press of America, 1993); John Wodarski and M. D. Feit, "Adolescent Preventive Health: A Social and Life Group Skills Paradigm" (paper presented at the American Public Health Association annual conference, San Francisco, October 1993); D. Hedin, "Students as Teachers: A Tool for Improving School," Social Policy 17 (Winter 1987): 42-47.

22. Masten, "Resilience in Individual Development" (n. 15 above).

23. A. Masten and J. D. Coatsworth, "Competence, Resilience and Psychopathology," in Cicchetti and Cohen, eds. (n. 14 above).

24. Coie et al. (n. 6 above).

25. Weissberg and Greenberg (n. 17 above).

26. Dumka et al. (n. 1 above).

27. R. M. Baron and D. A. Kenny, "The Moderator-Mediator Variable Distinction in Social Psychological Research: Conceptual, Strategic and Statistical Considerations," Iournal of Personality and Social Psychology 51, no. 6 (1986): 1173-82.

28. Rutter, "Protective Factors in Children's Responses" (n. 7 above); Werner and Smith, Vulnerable but Invincible (n. 4 above); H. I. McCubbin, A. I. Thompson, E. A. Thompson, K. E. Elver, and M. A. McCubbin, "Ethnicity, Schema and Coherence: Appraisal Processes for Families in Crisis," in McCubbin et al., eds. (n. 1 above).

29. Fraser, ed. (n. 2 above); Cohler, Stott, and Musick (n. 14 above).

30. L. J. Langua, M. W. Roosa, E. Schupak-Neuberg, M. L. Michaels, C. N. Berg, and L. F. Weschler, "Using Focus Groups to Guide the Development of a Parenting Program for Difficult-to-Reach, High-Risk Families," Family Relations 41 (1992): 163-68; C. Higgens, Youth Motivation: At-Risk Youth Talk to Program Planners (Philadelphia: Public/Private Ventures, 1988).

31. A. Bandura, "Self-Efficacy: Toward a Unifying Theory of Behavioral Change," Psychological Review 84 (1977): 191-215.

32. S. D. Rose and J. L. Edleson, Working with Children and Adolescents in Groups (San Francisco: Jossey-Bass, 1987); S. D. Rose, "Putting the Group into Cognitive-Behavioral Treatment," Social Work with Groups 13 (1990): 71-83, Working with Troubled Youth: CognitiveBehavioral Interactive Group Therapy (Thousand Oaks, Calif.: Sage, 1988); Wodarski and Feit (n. 21 above); Wodarski and Wodarski (n. 21 above); J. Martin, Mastering Instruction (New York: Allyn \& Bacon, 1981); R. Bangert-Drowns, "The Effects of School-Based Substance 
Abuse Education," Iournal of Drug Education 18, no. 3 (1988): 243-64; B. Bry, "Empirical Foundations of Family-Based Approaches to Adolescent Substance Abuse," in Preventing Adolescent Drug Abuse: Intervention Strategies, Research Monograph no. 47, ed. T. Glynn, C. G. Leukfield, and J. P. Ludford (Rockville, Md.: National Institute of Drug Abuse, 1983), pp. 154-71; R. Slavin, N. Karweit, and N. Madden, Effective Programs for Students at Risk (Needham Heights, Mass.: Allyn \& Bacon, 1989); N. Tobler, "Meta-analysis of 143 Adolescent Drug Prevention Programs: Quantitative Outcome Results of Program Participants Compared to a Control or Comparison Group," Iournal of Drug Issues 16, no. 4 (1986): 53768; P. Trower, Radical Approaches to Social Skills Training (New York: Methuen, 1986).

33. Dumka et al. (n. 1 above).

34. L. J. Schweinhart and D. P. Weikart, "The High/Scope Perry Preschool Program," in Fourteen Ounces of Prevention: A Casebook for Practitioners, ed. R. H. Price, E. L. Cowen, R. P. Lorion, and J. Ramos-McKay (Washington D.C.: American Psychological Association, 1988), pp. 53-65; L. J. Schweinhart, H. V. Barnes, and D. P. Weikart, Significant Benefits: The High/ Scope Perry Preschool Study Through Age 27 (Ypsilanti, Mich.: High/Scope Press, 1993); I. Lazar, R. B. Darlington, H. Murray, J. Royce, and A. Sniper, "Lasting Effects of Early Education: A Report from the Consortium for Longitudinal Studies," Monographs of the Society for Research in Child Development, serial no. 195, vol. 47, nos. 2-3 (1982); Committee for Economic Development, Children in Need: Investment Strategies for the Educationally Disadvantaged (New York: Committee for Economic Development, 1987).

35. K. White, "Efficacy of Early Intervention," Iournal of Special Education 19, no. 4 (1985): 401-16.

36. M. W. Lipsey and D. B. Wilson, "The Efficacy of Psychological, Educational, and Behavioral Treatment," American Psvchologist 48 (1993): 1181-1209.

37. R. Haskins, "Beyond Metaphor: The Efficacy of Early Childhood Education," American Psychologist 44 (1989): 274-83.

38. Weissberg and Greenberg (n. 17 above), p. 46.

39. J. R. Berrueta-Clement, L. J. Schweinhart, W. S. Barnett, A. S. Epstein, and D. P. Weikart, Changed Lives: The Effects of the Perry Preschool Program on Youths through Age 19 (Ypsilanti, Mich: High/Scope Press, 1984).

40. E. Zigler and S. Styfco, "Head Start: Criticisms in a Constructive Context," American Psychologist 49 (1994): 127-32.

41. E. Zigler and S. Styfco, Head Start and Beyond: A National Plan for Extended Childhood Intervention (New Haven, Conn.: Yale University Press, 1993).

42. V. E. Lee, J. Brooks-Gunn, and E. Schnur, "Are Head Start Effects Sustained? A Longitudinal Follow-Up Comparison of Disadvantages Children Attending Head Start, No Preschool, and Other Preschool Programs," Child Development 61 (1990): 495-507.

43. E. Zigler, C. S. Piotrkowski, and R. Collins, "Health Services in Head Start," Annual Review of Public Health 15 (1994): 511-34.

44. E. Zigler and S. Muenchow, Head Start: The Inside Story of America's Most Successful Educational Experiment (New York: Basic, 1993).

45. L. Datta, "Another Spring and Other Hopes: Some Findings from National Evaluations of Project Head Start," in Project Head Start: A Legacy of the War on Poverty, ed. E. Zigler and J. Valentine (New York: Free Press, 1979), pp. 405-32.

46. Consortium for Longitudinal Studies, As the Twig Is Bent: Lasting Effects of Preschool Programs (Hillsdale, N.J.: Erlbaum, 1983).

47. A. J. Reynolds, "Effects of a Preschool plus Follow-on Intervention for Children at Risk," Developmental Psychology 30 (1994): 787-804, “One Year of Preschool Intervention or Two: Does It Matter?” Early Childhood Research Quarterly 10 (1995): 1-31.

48. A. J. Reynolds and J. Temple, "Quasi-Experimental Estimates of the Effects of a Preschool Intervention: Psychometric and Econometric Comparisons," Evaluation Review 19 (1995): 347-73.

49. A. J. Reynolds, M. Mehana, and J. Temple, "Does Preschool Intervention Affect Children's Perceived Competence?" Iournal of Applied Developmental Psychology 16 (1995): 211-30.

50. Reynolds, "Effects of a Preschool," and "One Year of Preschool Intervention or Two" (both in n. 47 above).

51. Zigler and Styfco, "Head Start: Criticisms in a Constructive Context" (n. 40 above); Weissberg and Greenberg (n. 17 above). 
52. Fraser, ed. (n. 2 above).

53. Schweinhart, Barnes, and Weikart (n. 34 above).

54. A. J. Sameroff, "Prevention of Developmental Psychopathology Using the Transactional Model: Perspectives on Host, Risk Agent and Environmental Interactions," in The Prevention of Mental Disorders: Progress, Problems, and Prospects, ed. National Institute of Mental Health (Washington D.C.: National Institute of Mental Health, 1991).

55. A. J. Reynolds, "Long-Term Effects of the Chicago Child-Parent Center Program up to Age 15" (University of Wisconsin-Madison, 1997).

56. H. Yoshikawa, "Prevention of Cumulative Protection: Effects of Early Family Support and Education on Chronic Delinquency and Its Risks," Psvchological Bulletin 115 (1994): 1-27, "Long-Term Effects of Early Childhood Programs on Social Outcomes and Delinquency," Future of Children 5, no. 3 (1995): 51-75; E. Zigler, C. Taussig, and K. Black, "Early Childhood Intervention: A Promising Preventative for Juvenile Delinquency," American Psychologist 47 (1992): 997-1006.

57. J. D. Hawkins, R. F. Catalano, and D. D. Brewer, "Preventing Serious, Violent and Chronic Juvenile Offending: Effective Strategies from Conception to Age 6," in A Sourcebook on Serious, Violent, and Chronic Juvenile Offenders, ed. J. C. Howell, B. Krisberg, J.J. Wilson, and J. D. Hawkins (Newbury Park, Calif.: Sage, 1995), pp. 47-60; P. H. Tolan and N. G. Guerra, "Prevention of Delinquency: Current Status and Issues," Applied and Preventive Psychology 3 (1994): 251-73; G. H. DeFriese, C. L. Crossland, C. E. Pearson, and C. J. Sullivan, "Comprehensive School Health Programs: Current Status and Future Prospects," Journal of School Health 60 (1990): 127-90; D. Kirby, "School-Based Programs to Reduce Sexual Risk-Taking Behaviors," Journal of School Health 62 (1992): 280-87.

58. R. J. Haggerty, "President's Report," in the William T. Grant Foundation Annual Report, 1988 (New York: William T. Grant Foundation, 1988); Weissberg and Greenberg (n. 17 above).

59. Joy Dryfoos, Adolescents at Risk: Prevalence and Prevention (New York: Oxford University Press, 1990).

60. B. Maughan, "School Experiences as Risk/Protective Factors," in Studies of Psychosocial Risk: The Power of Longitudinal Data, ed. M. Rutter (New York: Cambridge University Press, 1988), pp. 200-220.

61. J. M. Richman and G. L. Bowen, "School Failure: An Ecological-InteractionalDevelopmental Perspective," in Fraser, ed. (n. 2 above), pp. 95-116.

62. R. P. Weissberg and M. J. Elias, "Enhancing Young People's Social Competence and Health Behavior: An Important Challenge for Educators, Scientists, Policy Makers, and Funders," Applied and Preventive Psychology: Current Scientific Perspectives 3 (1993): 179-90.

63. S. T. Ennett, N. S. Tobler, C. L. Ringwalt, and R. I. Flewelling, "How Effective Is Drug Abuse Resistance Education? A Meta-analysis of Project DARE Outcome Evaluations," American Journal of Public Health 84 (1994): 1394-1401.

64. Kirby (n. 57 above).

65. M. B. Shure and G. Spivack, "Interpersonal Problem-Solving in Young Children: A Cognitive Approach to Prevention," American Journal of Community Psychology 10 (1982): 341-56; R. Mills, R. Dunham, and G. Alpert, "Working with High-Risk Youth in Prevention and Early Intervention Programs: Toward a Comprehensive Wellness Model," Adolescence 23 (1988): 643-60; Bangert-Drowns (n. 32 above); Rose and Edleson (n. 32 above); Rose, "Putting the Group into Cognitive-Behavioral Treatment," and Working with Troubled Youth (both in n. 32 above); Wodarksi and Feit (n. 21 above); Wodarski and Wodarski (n. 21 above); Bry (n. 32 above); Slavin, Karweit, and Madden (n. 32 above).

66. D. R. Dupper and C. H. Krishef, "School-Based Social-Cognitive Skills Training for Middle School Students with School Behavior Problems," Children and Youth Services Review 15, no. 2 (1993): 131-42.

67. J. E. Lochman, W. M. Nelson, and J. P. Sims, "A Cognitive Behavioral Program for Use with Aggressive Children," Iournal of Clinical Child Psychology 10 (1981): 146-48.

68. J. E. Lochman, P. R. Burch, J. F. Curry, and L. B. Lampron, "Treatment and Generalization Effects of Cognitive-Behavioral and Goal-Setting Interventions with Aggressive Boys," Iournal of Consulting and Clinical Psychology 52 (1984): 915-16.

69. For a full discussion of effectiveness in intervention programs of this type, see Rose and Edleson (n. 32 above); Rose, "Putting the Group into Cognitive-Behavioral Treatment" and Working with Troubled Youth (both in n. 32 above). 
70. Urie Bronfenbrenner, The Ecology of Human Development (Cambridge, Mass.: Harvard University Press, 1974), and "Beyond Policies without People: An Ecological Perspective on Child and Family Policy," in Children, Families, and Government: Perspectives on American Social Policy, ed. E. Zigler, S. L. Kagan, and E. Klugman (New York: Cambridge University Press, 1983).

71. Haggerty (n. 58 above).

72. Weissberg and Greenberg (n. 17 above).

73. C. A. Johnson, M. A. Pentz, M. E. Weber, J. H. Dwyer, N. Baer, D. P. MacKinnon, W. B. Hansen, and B. R. Flay, "Relative Effectiveness of Comprehensive Community Programming for Substance Abuse Prevention with High-Risk and Low-Risk Adolescents," Iournal of Consulting and Clinical Psychology 58 (1990): 447-56; M. A. Pentz, J. H. Dwyer, D. P. MacKinnon, B. Flay, W. B. Hansen, E. Y. I. Wang, and C. A. Johnson, "A Multicommunity Trial for Primary Prevention of Adolescent Drug Abuse," Iournal of the American Medical Association 261 (1989): 3259-66.

74. Kirby and Fraser (n. 5 above).

75. Rose and Edleson (n. 32 above); Rose, Working with Troubled Youth (n. 32 above).

76. Weissberg and Greenberg (n. 17 above); Rose, Working with Troubled Youth (n. 32 above).

77. Fraser, ed. (n. 2 above); A. Masten, "Humor and Competence in School-Aged Children," Child Development 57 (1986): 461-73.

78. R. D. Felner, S. Brand, D. L. DuBois, A. M. Adan, P. F. Mulhall, and E. G. Evans, "Socioeconomic Disadvantage, Proximal Environmental Experiences and Socioemotional and Academic Adjustment in Early Adolescence: Investigation of a Mediated Effects Model," Child Development 66 (1995): 774-92.

79. Dumka et al. (n. 1 above).

80. D. Bryant and K. Maxwell Bryant, "The Effectiveness of Early Intervention for Disadvantaged Children," in The Effectiveness of Early Intervention, ed. M. J. Guralnick (Baltimore: Paul H. Brookes, 1997).

81. White (n. 35 above), p. 414.

82. D. T. Campbell, "Can We Be Scientific in Applied Social Science?” Evaluation Studies Review Annual 9 (1984): 26-48, quotes on pp. 30, 34.

83. D. Dobson and T. J. Cook, "Avoiding Type III Error in Program Evaluation: Results from a Field Experiment," Evaluation and Program Planning 3 (1980): 269-76.

84. Dumka et al. (n. 1 above); Langua et al. (n. 30 above); P. R. Smokowski, "Early Intervention Memories Ten Years Post-Program: A Qualitative Child Parent Center Implementation Evaluation" (University of Wisconsin-Madison, 1997).

85. Institute of Medicine, Reducing Risks for Mental Disorders: Frontiers for Preventive Intervention Research (Washington, D.C.: National Academy Press, 1994); T. D. Cook and D. T. Campbell, Quasi-Experimentation: Design and Analyses Issues for Field Settings (Chicago: Rand McNally, 1979); Campbell (n. 82 above).

86. D. S. Cordray, "Quasi-Experimental Analysis: A Mixture of Methods and Judgement," in Advances in Quasi-Experimental Design and Analysis: New Directions for Program Evaluation, ed. W. Trochim (San Francisco: Jossey-Bass, 1986), pp. 9-27; E. G. Guba, "Naturalistic Evaluation," in Evaluation Practice in Review: New Directions for Program Evaluation, vol. 34, ed. D. S. Cordray, H. S. Bloom, and R. J. Light (San Francisco: Jossey-Bass, 1987), pp. 23-43.

87. Reynolds, Mehana, and Temple (n. 49 above).

88. Weissberg and Greenberg (n. 17 above).

89. Yoshikawa, "Long-Term Effects of Early Childhood Programs on Social Outcomes and Delinquency" (n. 56 above). 